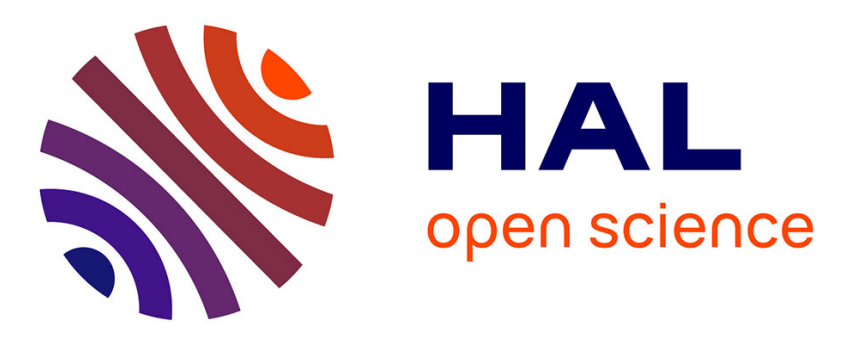

\title{
Estimating babassu palm density using automatic palm tree detection with very high spatial resolution satellite images
}

Alessio Moreira dos Santos, Danielle Mitja, Eric Delaître, Laurent Demagistri, Izildinha de Souza Miranda, Thérèse Libourel Rouge, Michel Petit

\section{To cite this version:}

Alessio Moreira dos Santos, Danielle Mitja, Eric Delaître, Laurent Demagistri, Izildinha de Souza Miranda, et al.. Estimating babassu palm density using automatic palm tree detection with very high spatial resolution satellite images. Journal of Environmental Management, 2017, 193, pp.40 - 51. 10.1016/j.jenvman.2017.02.004 . ird-01715147

\author{
HAL Id: ird-01715147 \\ https://hal.ird.fr/ird-01715147
}

Submitted on 22 Feb 2018

HAL is a multi-disciplinary open access archive for the deposit and dissemination of scientific research documents, whether they are published or not. The documents may come from teaching and research institutions in France or abroad, or from public or private research centers.
L'archive ouverte pluridisciplinaire HAL, est destinée au dépôt et à la diffusion de documents scientifiques de niveau recherche, publiés ou non, émanant des établissements d'enseignement et de recherche français ou étrangers, des laboratoires publics ou privés. 
1 Estimating babassu palm density using automatic palm tree detection with very high

2

3 Alessio Moreira dos Santos ${ }^{\mathrm{ab}^{*}}$, Danielle Mitja ${ }^{\mathrm{c}}$, Eric Delaître ${ }^{\mathrm{c}}$, Laurent Demagistri ${ }^{\mathrm{c}}$, Izildinha de

4 Souza Miranda ${ }^{\mathrm{a}}$, Thérèse Libourel ${ }^{\mathrm{c}}$, Michel Petit ${ }^{\mathrm{d}}$.

5

6

7

8

9

a. Universidade Federal Rural da Amazonia (UFRA), CP.917, Belém, Pará, 66077-530, Belém, Brazil. alessiomsag@gmail.com, izildinha.miranda@ufra.edu.br

b. Universidade Federal do Sul e Sudeste do Pará (UNIFESSPA), Folha 31, Quadra 07, Lote Especial, Nova Marabá, 68507-590, Marabá, Brazil.

c. Institut de Recherche pour le Développement (IRD), UMR 228 ESPACE DEV, 500, Rue Jean François Breton 34093 Montpellier, France. danielle.mitja@ird.fr, eric.delaitre@ird.fr, laurent.demagistri@ird.fr, therese.libourel@univ-montp2.fr

d. Institut de Recherche pour le Développement (IRD), 911 avenue Agropolis BP64501, 34394 Montpellier Cedex 05, France. michel.petit@ird.fr

*Corresponding author :

Alessio Moreira dos Santos : alessiomsag@gmail.com 


\section{Abstract}

High spatial resolution images as well as image processing and object detection algorithms are recent technologies that aid the study of biodiversity and commercial plantations of forest species. This paper seeks to contribute knowledge regarding the use of these technologies by studying randomly dispersed native palm tree. Here, we analyze the automatic detection of large circular crown (LCC) palm tree using a high spatial resolution panchromatic GeoEye image $(0.50 \mathrm{~m})$ taken on the area of a community of small agricultural farms in the Brazilian Amazon. We also propose auxiliary methods to estimate the density of the LCC palm tree Attalea speciosa (babassu) based on the detection results. We used the "Compt-palm" algorithm based on the detection of palm tree shadows in open areas via mathematical morphology techniques and the spatial information was validated using field methods (i.e. structural census and georeferencing). The algorithm recognized individuals in life stages 5 and 6, and the extraction percentage, branching factor and quality percentage factors were used to evaluate its performance. A principal components analysis showed that the structure of the studied species differs from other species. Approximately $96 \%$ of the babassu individuals in stage 6 were detected. These individuals had significantly smaller stipes than the undetected ones. In turn, $60 \%$ of the stage 5 babassu individuals were detected, showing significantly a different total height and a different number of leaves from the undetected ones. Our calculations regarding resource availability indicate that 6,870 ha contained 25,015 adult babassu palm tree, with an annual potential productivity of $27.4 \mathrm{t}$ of almond oil. The detection of LCC palm tree and the implementation of auxiliary field methods to estimate babassu density is an important first step to monitor this industry resource that is extremely important to the Brazilian economy and thousands of families over a large scale. 
Keywords: Shadow detection; Mathematical morphology; Density estimate; Remote sensing; Brazilian Amazon

\section{Introduction}

The babassu (Attalea speciosa Mart. ex Spreng.) is a palm tree species native to dense and humid forests that is distributed across approximately $200,000 \mathrm{~km}^{2}$ of forests and savannas in Brazil, with optimal development in secondary environments (Anderson and Anderson, 1985; May et al., 1985; Barot et al., 2005; Santos and Mitja, 2011; Coelho et al., 2012). Recent research emphasized the importance of this palm tree to industry, given its potential for biodiesel production (Da Rós et al., 2014) and bioenergy (Protásio et al., 2014); to ethnobotany, given its use diversity (Araujo and Lopes, 2012; Martins et al., 2014); to anthropology, given its economic and social importance for small farmers (Porro and Porro, 2014); and to medicine because babassu palm trees can become infested with triatomines, which transmit Chagas disease (Dias et al., 2014). Recently, babassu oleaginous almonds were considered as the third most important non-wood product of plant extractivism in Brazil $(89,739 \mathrm{t} / \$ 56.7$ million in 2013; IBGE, 2013). Nevertheless, a gap exists between the knowledge of this species and use of technologies that might aid in its management and sustainable exploitation.

In forest plantations, information on tree or palm tree density is obtained using remotesensing techniques that aid in productivity monitoring, planning and management of African oil palm tree (Shafri et al., 2011; Srestasathiern and Rakwatin, 2014) and eucalypt (Whiteside et al., 2011; Zhou et al., 2013) plantations. The spatial information provided regarding the number of trees or palm trees enables (among other things) the identification of excessive mortality areas (Zhou et al., 2013) and the prediction of production dates (Malek et al., 2014), which are essential for resource management and conservation (Engler et al., 2013). 
As an alternative to time-demanding tasks of individually counting trees or palm trees in the field, automatic-detection methods were developed using high spatial resolution images. The primary objective of this detection is to determine the location of the tree or palm tree crowns in an image (Srestasathiern and Rakwatin, 2014). Studies apply different techniques to delimit tree and palm tree crowns based on the value of each pixel in the image (Erikson and Olofsson, 2005). Some of the techniques used include the marked-point process (MPP) via Worldview 1 and Worldview 2 multispectral images (Zhou et al., 2013), the maximum local detection method using Kodak DCS 460 CIR and UltracamD digital camera images (Pouliot et al., 2002; Hirschmugl et al., 2007), and a technique based on the structure of the elements using an airborne AISA hyperspectral image (Shafri et al., 2011). These techniques are generally used for homogeneous forest plantations disposed along a line; not having other species within the plantation avoids confusion when analyzing the images.

The mapping of tree crowns in non-planted areas (i.e., those dispersed in cultivated areas or in homogeneous or heterogeneous natural forests) can be based on the detection of crowns via object-oriented classification using IKONOS and GeoEye images (Aouragh et al., 2013), the wavelet-transform technique (Zhang et al., 2006; Ghiyamat and Shafri, 2010), or via supervised classification techniques such as spectral angle mapper, a linear discriminant analysis, and the maximum likelihood method (Clark et al., 2005), both techniques use an airborne HYDICE hyperspectral image.

Few studies have used image-based palm tree detection directed toward regular African oil palm tree plantations. Currently, babassu plantations are not found in Brazil, which might explain why this species has not yet been evaluated using automatic detection via images from recent satellites such as GeoEye, Ikonos, Worldview or Quickbird (which offer a spatial resolution of less than $1 \mathrm{~m}$ ). The development of images with a resolution of less than $1 \mathrm{~m}$ enabled the more precise detection of small objects such as tree crowns in 
agricultural areas and their different shapes (Aouragh et al., 2013) using canopy delineation algorithms (Culvenor, 2002).

Although the classic algorithms developed for crown delineation fundamentally assume that the center of a crown appears radiometrically brighter than its edge (Culvenor, 2002), the algorithm developed by Demagistri et al. (2014), adapted for open environments, extracts the image pixels that correspond to shadows using the mathematical morphology technique (Serra, 1982; Haralick et al., 1987). This algorithm permits the detection of palm trees in pastures and agricultural plantations with low-to-average palm tree density. This image analysis technique is important (Soille and Pesaresi, 2002; Giada et al., 2003) for the detection of individual trees (Jiang and Lin, 2013) and other objectives. This technique is known as "morphology" because it analyses the content and shape of the object and called "mathematical" because it is based on set theory, integral geometry, and algebraic structure (Giada et al., 2003). Therefore, this algorithm has been used to detect the babassu palm tree in open agricultural environments.

Studies on tree and palm tree-crown detection do not usually employ field methods to validate the spatial information (Clark et al., 2005; Zhang et al., 2006; Hirschmugl et al., 2007; Ghiyamat and Shari, 2010; Shafri et al., 2011; Aouragh et al., 2013; Malek et al., 2014; Srestasathiern and Rakwatin, 2014). When used, these methods are typically restricted to measure crown diameter and individual density (Pouliot et al., 2002, Zhou et al., 2013), although other structural characteristics of the individuals might affect their detection using the algorithm. Therefore, understanding these characteristics is an important step to improve the reliability of spatial information.

A large diversity of palm trees exists in the Amazon region, including 195 species and 35 genera. The most important genera include Attalea and Astrocaryum, each with 28 species (Pintaud et al., 2008). In addition to Attalea speciosa (babassu), other large circular crown 
(LCC) species such as Attalea maripa (inajá), Astrocaryum aculeatum (tucumã), Oenocarpus bacaba (bacaba) and Mauricia flexuosa (buriti) are distributed in an isolated and random manner (D. Mitja, Personal communication). Because no methods are described in the literature that enable differentiation among LCC palm tree types using a high-resolution image, estimating the density of a species of interest (e.g., the babassu) using automatic detection is a real challenge.

In the present study, we analyzed the automatic detection of LCC palm trees using a high spatial resolution panchromatic image (GeoEye1 sensor, 0.50-m resolution, July/2013) taken on a community of small farms in the Brazilian Amazon after validating the remotesensing data using photo-interpretation and field methods. Based on the automatic detection results, we implemented auxiliary field methods to estimate babassu density.

\section{Material and Methods}

\subsection{Characterization of the study area}

This study was conducted in small farmlands in Benfica (S 05² $\left.16^{\prime} 20^{\prime \prime}, \mathrm{W} 49^{\circ} 50^{\prime} 25^{\prime \prime}\right)$, (Itupiranga State of Pará (PA), southeast of the Brazilian Amazon) (Fig. 1). This site has 9,501 ha, and its occupation started in 1986 successively by farmers and settlers. Its land regularization was consolidated by the National Institute of Colonization and Agrarian Reform (Instituto Nacional de Colonização e Reforma Agrária; INCRA) in 1996 (Arnauld de Sartre, 2004). The latest estimate indicated 183 agricultural establishments and approximately 1,000 people in the community (Ritter et al., 2009). 


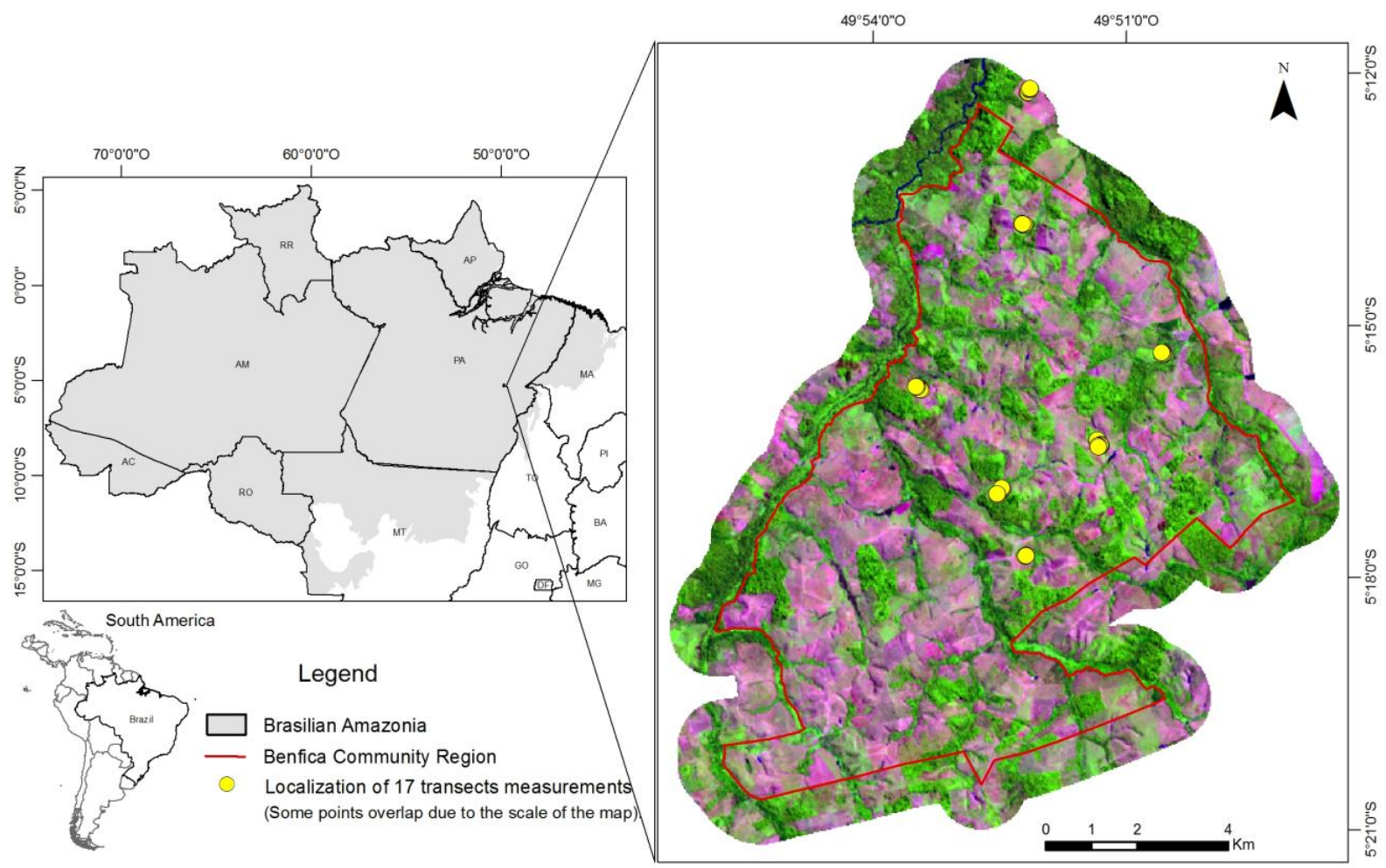

Fig. 1. The study area (Benfica, PA), located southeast of the Brazilian Amazon, shown by a

141

Landsat 8-OLI 2013 image (RGB: B6, B5, B4).

*Two transects were near but outside the limit of Benfica community.

The vegetation in this area is upland tropical forest, characterized by the presence of lianas and palm trees (Mitja and Miranda, 2010). The dense forest has a canopy between 25 and $30 \mathrm{~m}$ in height, although some trees (e.g., Bertholletia excelsa H.B.K) reach a height of over $50 \mathrm{~m}$ (Bertrand, 2009). Landsat 8-OLI images taken in 2013 (Fig. 1) showed that primary and old secondary forests (in dark green colors) covered 34\% of the area in Benfica, whereas degraded pastures or pastures with little cover (in purple and pink colors) represented $31 \%$; pastures in good states and young secondary forests (in light green colors) accounted for $31 \%$ of the area (Eric Delaître, Personal communication).

When forests are converted into pastures, some palm trees and timber species are maintained (Mitja et al., 2008; Santos and Mitja, 2011), thereby contributing to the 
composition of the local landscape that includes pastures containing woody species (15\%) and pastures with babassu (12\%; Sampaio, 2008). The high reproductive plasticity of babassu favors its development in agricultural areas (Barot et al., 2005) because the use of fire for agricultural management contributes to the germination and regeneration of babassu individuals (Mitja and Ferraz, 2001). Thus, the different densities of the babassu in the study area are partially a result of its resilience to natural and anthropogenic disturbances, insofar as (similar to some other species) it has particular morphological characteristics and reproductive strategies that influence its phenology and gene flow (Montúfar et al., 2011).

The climate is tropical humid with average temperature of $26^{\circ} \mathrm{C}$. The average annual rainfall is $1,700 \mathrm{~mm}$, distributed irregularly throughout the year. The region's two seasons are defined by the movements of the intertropical convergence zone: the rainy season, which typically lasts approximately 8 months (October to May); and the dry season, which typically lasts 4 months (June to September; Bertrand, 2009).

A variety of soils exists along the toposequences: (i) oxisol, with a thick B horizon rich in ferruginous nodules; (ii) cambisol, with an incipient $\mathrm{B}$ horizon and a C horizon located close to the surface; and (iii) gleysol, with an A horizon rich in organic matter, A and B horizons with little clay, and hydromorphy along the entire profile (Ritter et al., 2009). As is the norm for most arable lands in the Amazon, the soil fertility of the study area is low (Ritter et al., 2009).

\subsection{Field data}

The information obtained in the field enabled the definition of the proportion of babassu in the set of LCC palm trees. There are five LCC palm tree species in Benfica, three are more frequent, babassu, inajá and tucumã, and two rare species, bacaba and buriti (Santos 
and Mitja, 2011; Danielle Mitja, Personal communication). In a 487 ha pasture area of the study site (=62-plots), we observed that $93.6 \%$ of the LCC palm trees found were babassu. This result was used to estimate the babassu density based on the automatic LCC palm tree detection results.

A total of 17 transects were sampled in pastures of different ages $(1,3,5,7$ and 9 years), with a total sampling area of 1.3 ha (Fig. 1). In these transects, we noted that $46.51 \%$ of the detected palm trees belonged to stage 5, whereas $53.49 \%$ belonged to stage 6 .

A total of 150 babassu across three development stages were inventoried in the pasture areas. Out of these babassu, 105 were in stage 6 (adults with an aerial stipe and signs of male and/or female reproductive organs), 30 were in stage 5 (juvenile with an aerial stipe, regardless of sheath coverage, and without the signs of male or female reproductive organs), and 15 were in stage 4 (juvenile with a terminal bud at the soil surface level, with well-visible leaf sheaths).

The structural information obtained in the field included circumference at breast height, circumference at the base of the stipe, number of leaves, total height, stipe height, and crown circumference (Fig. 2). This structural information was also obtained for two other LCC palm trees species, inajá (31 individuals) and tucumã (30 individuals).

All these palm trees were georeferenced using the global positioning system (GPS; model: GARMIN 62stc) to be located in the GeoEye 2013 image and identify the individuals that had been detected using the detection algorithm. 


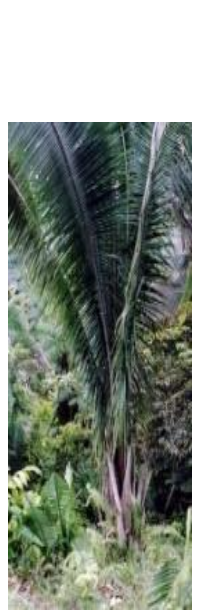

Stage 4

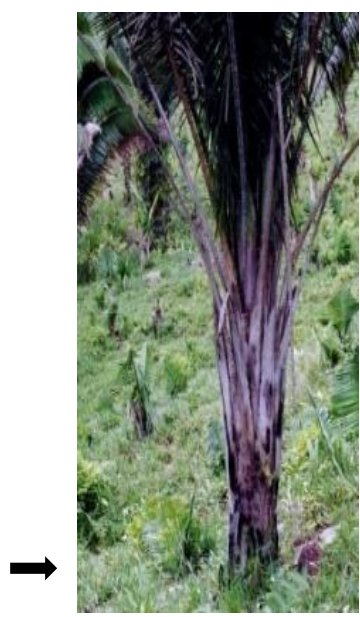

Stage 5

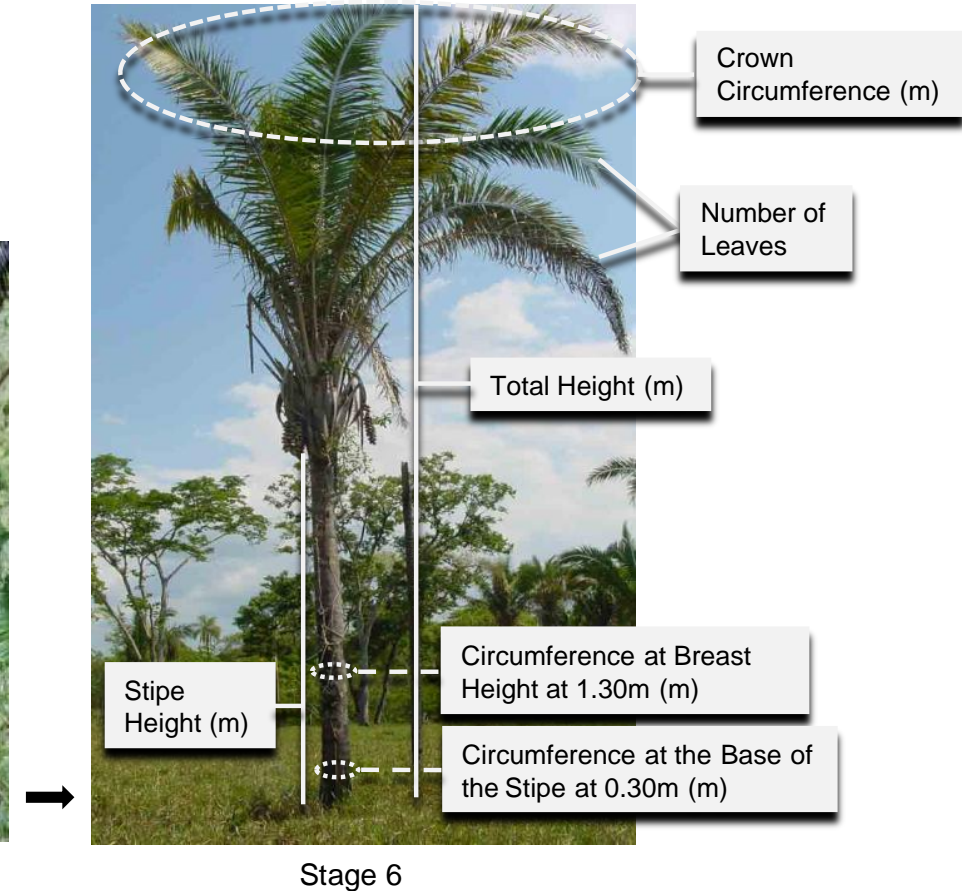

Stage 6

Fig. 2. Life-cycle stages of the babassu palm trees studied in Benfica and the structural information obtained

2.3. Remote sensing image

The present study used a GeoEye-1 satellite image in panchromatic mode (intrinsic spatial resolution of $0.41 \mathrm{~m}$ resampled to $0.50 \mathrm{~m}$, acquired on July 12, 2013 and orthorectified. The image has $15 \times 15 \mathrm{~km}$ of dimension, and the following angles: $56.09^{\circ}$ of sensor azimuth, $79.03^{\circ}$ of sensor elevation, $42.575^{\circ}$ of sun azimuth, and $56.09^{\circ}$ of sun elevation. The image encompasses the entire surface of Benfica $(9,501$ ha). To comply with the requirements of the LCC palm tree detection algorithm, a radiometric correction was applied to the 2013 image so as to get the same dynamic range as the 2009 one (spatial resolution of $0.50 \mathrm{~m}$ ), which was used to obtain the palm tree detection algorithm.

\subsection{LCC palm tree detection algorithm development and evaluation}


An "Compt-palm" algorithm adapted to open environments was developed to detect

215 the following LCC palm trees: babassu, inajá, tucumã, bacaba and buriti (Demagistri et al., 2014). A panchromatic GeoEye 2009 image of Benfica was used in the algorithmdevelopment process. At first, shadows palm trees are extracted using mathematical morphology techniques; then each shadow object (which corresponds to a potential palm tree) undergoes a supervised classification by calculating a decision coefficient used to assign that object a particular class label between "palm tree shadow" and "other shadow". The shadow extraction protocol proceeds as follows:

i) Smoothing of the panchromatic image: this first filter removes the noise from the image;

ii) Local adaptive filtering based on the mean and standard deviation of a moving window: zones with a strong local contrast (i.e. the shadows) are extracted;

iii) Morphological closing: the first step in cleaning the shadow extraction results;

iv) Connected components extraction: labeling of independent shadow objects;

v) Object size thresholding: the second step in cleaning the shadow extraction results.

Afterwards, shadow objects are classified using a supervised classification based on a distance criterion and a decision rule process. These steps are detailed below:

i) Classifier training with two sets of shadow images: 75 cropped images of "palm tree shadows" and 75 cropped images of "other shadows"; 25 normalized shape characteristics and invariants are computed on the whole set of the cropped images (see below for some details).

ii) Calculation of classifier entry parameters for each potential palm tree shadow and selection of the 5 closest shadow objects (Euclidian distance computation) within the training set. 
iii) Score calculation, according to the class of the closest shadow objects, enabling appropriate classification of each shadow.

To characterize the palm tree shadows, we worked with the shape characteristics and

241 invariant described in Torres-Méndez et al. (2000). For each shadow image, we first compute

242 its moment of inertia (1 parameter). Then, using 12 concentric circles centered on the shadow

243 centroid we count for each circle the number of intensity changes that occur (shadow/no-

244 shadow) and the normalized difference of the two largest arcs that are not part of the shadows

245 (12x2 parameters).

The result is a list of points in image or cartographic coordinates that can be compared

247 with data obtained using image photo-interpretation. The steps by which the LCC palm tree 248 detection algorithm proceeds are shown in Fig. 3.

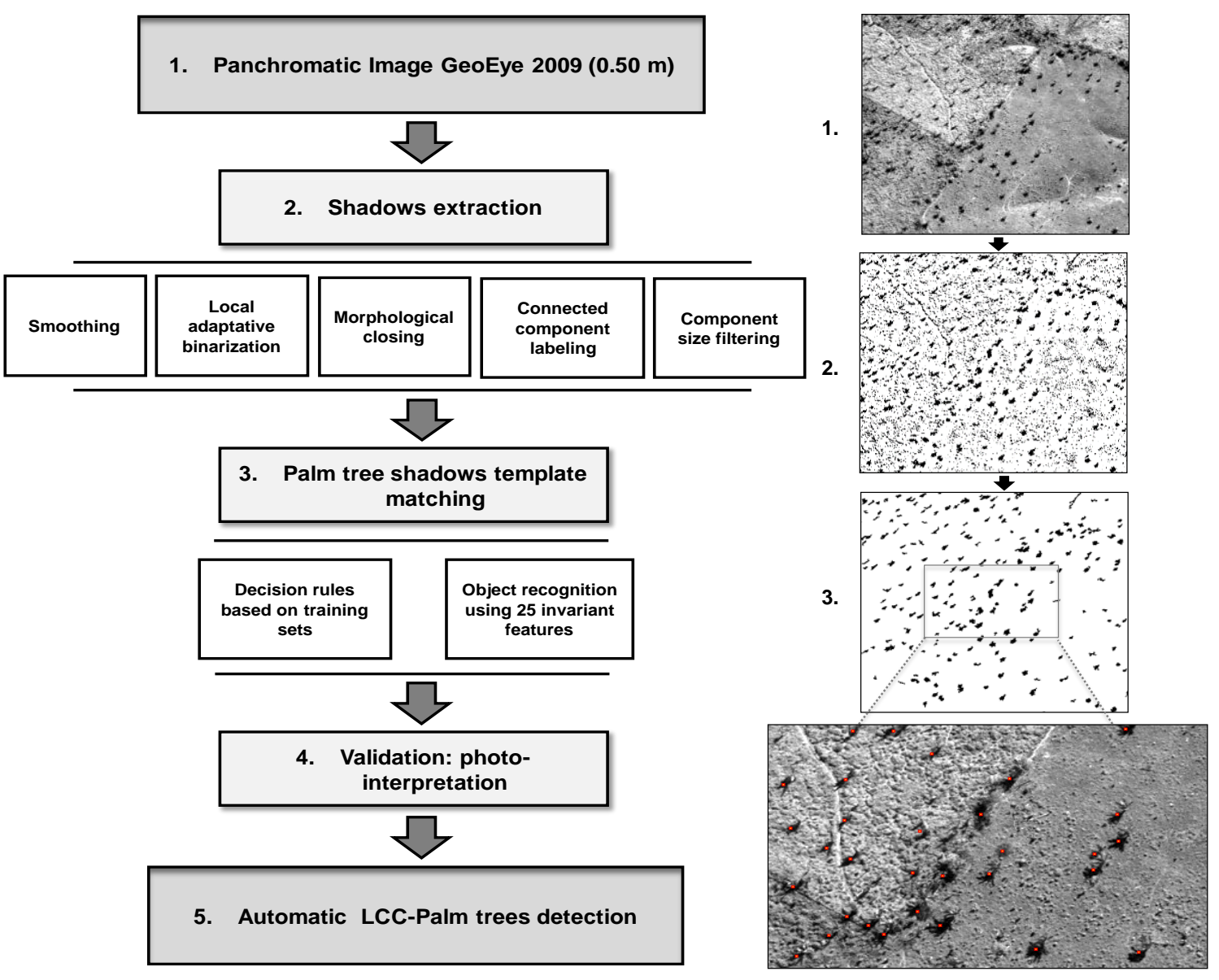


Fig. 3. Representation of the steps of the LCC palm trees automatic detection algorithm (adapted from Demagistri et al., 2014)

The algorithm was validated using image photo interpretation via a sample of 334 points observed over 16 cells of 1-ha, distributed in pastures of low and average babassu density in the study area.

To evaluate the precision and quality of the algorithm used, were considered the factors adopted by Shufelt (1999) and Luo et al. (2014); these factors can be based on image pixel classifications or on object shape and consider the numbers of true positives (TP), false positives (FP), and false negatives (FN). The first factor is the extraction percentage, given by the expression $100 * T P /(T P+F N)$, which can be understood as a measure of shadow extraction performance. The second factor is the branching factor, given by $F P / T P$, which measures delineation performance. The third factor is the quality percentage, given by $100^{*} T P /(T P+F P+F N)$, a general measure of method performance. According to Shufelt (1999), the use of these three measures completely evaluates model performance.

\subsection{Density map and calculation of the babassu resource estimate}

The palm tree location map produced by applying the algorithm to open environments on the GeoEye-1 2013 image was processed using ArcGis 10.2.2 with the Point Density tool to obtain the palm tree density map. The parameters used were the size of the raster cells (30$\mathrm{m}$ ) and the size and shape of the point search neighborhood (a $15 \mathrm{~m}$ radius circle, Fig. 4). The number of individuals per ha was used to calculate palm density. 
273

274

275

276

277

278

279

280

281

282

283

284

285

286

287

289

290

291

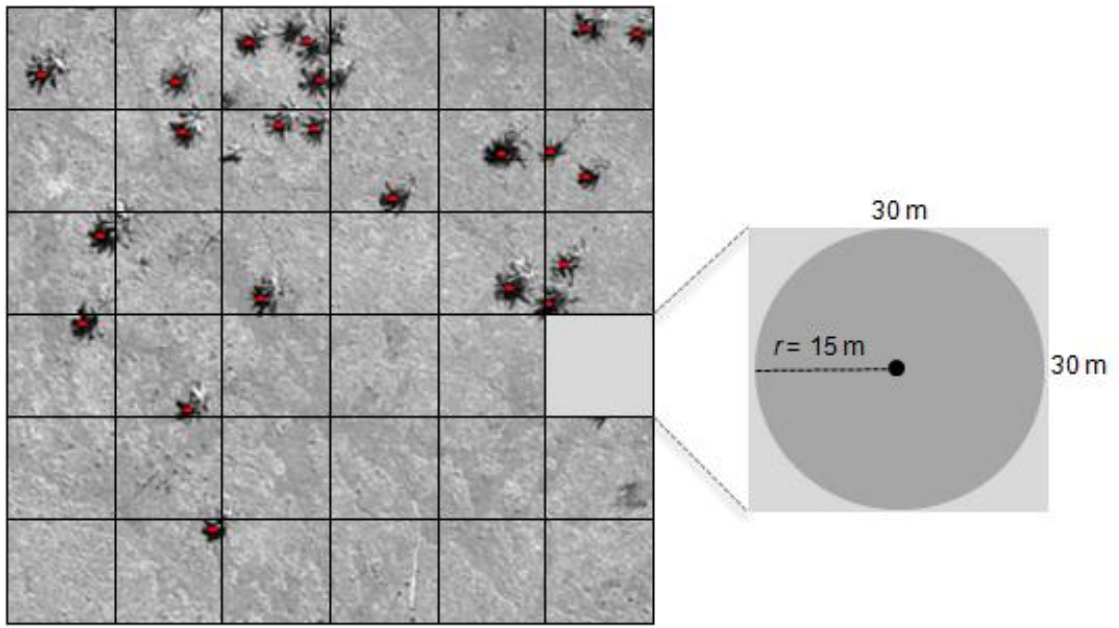

Fig. 4. Representation of the parameters used to elaborate the density map

The number of LCC palms actually present $(B)$ was defined as:

$B=A-(A \times F P) / 100+(A \times F N) / 100$; where: $\mathrm{A}=$ number of points indicated by the algorithm as corresponding to LCC palm trees; FP = False Positive; FN = False Negative. Then, based on information from Santos and Mitja (2011) was calculated the number of babassu as $93.6 \%$ of the total number of palm trees.

Therefore, we can calculate the number of babassu palm trees $(C)$ from the total LCC palm trees $(B)$.

$$
C=(B \times 93.6) / 100
$$

To obtain the proportion of stage 5 and 6 individuals in the pastures we use a total density of palm trees in of 17 transects, with $46.51 \%$ of stage 5 and $53.49 \%$ of stage 6 . Therefore, we calculated the total numbers of babassu palm trees (detected and undetected) in stage $5(V)$ and stage $6(W)$ present in open areas in Benfica.

Adult palm trees (stage 6):

$$
\left\{\begin{array}{l}
C=V+W \\
\text { With } V=(46.51 \% \text { of } C), \text { and } \\
W=(53.49 \% \text { of } C)
\end{array}\right.
$$



method, we estimated the annual potential productivity of almond oil of Benfica, using (i) the estimated density of adults at Benfica and (ii) literature data on fruit production (24 $\mathrm{kg}$ of fruits / palm / year on average - Anderson, 1983), seed production (1 kg of seeds from $13 \mathrm{~kg}$ of fruits - Gonsalves, 1955), and oil production (1 kg of crude oil from $1.68 \mathrm{~kg}$ of almonds Frazão, 2001).

\subsection{Statistical analyses}

A principal components analysis (PCA) was used to verify differences in the structural characteristics of LCC palm trees species. The significance of the PCA was determined using the Monte Carlo permutation test at $\mathrm{p}<0.05$.

The structural characteristics of babassu palm trees at stages 5 and 6 were compared using the non-parametric Wilcoxon test, as were the structural characteristics of the individuals at each stage based on whether they were detected or not, using the algorithm. All statistical analyses were performed using the software R 3.1.2 (R Core Team, 2014) with the packages ADE-4 (Dray and Dufour, 2007; Dray et al., 2007).

\section{Results}

\subsection{Structural characteristics of the LCC palm trees}

The use of the shadow-detection algorithm detected the babassu palm trees and also other palm tree, especially those dominant in Benfica, such as inajá and tucumã.

In contrast, the PCA of the structures of the babassu, inajá and tucumã palm trees (all belonging to stage 6, i.e., adults) showed that the LCC palm trees differed structurally. The first two PCA axes explained $75.77 \%$ of the variance in the scatterplot. Axis 1 explained 
$39.71 \%$ of the variance, and the structural variables that contributed the most to this axis were circumference at breast height, circumference at the base of the stipe, number of leaves. The second axis explained $36.06 \%$ of the variance, and its most important variables were total height, stipe height (Fig. 5).

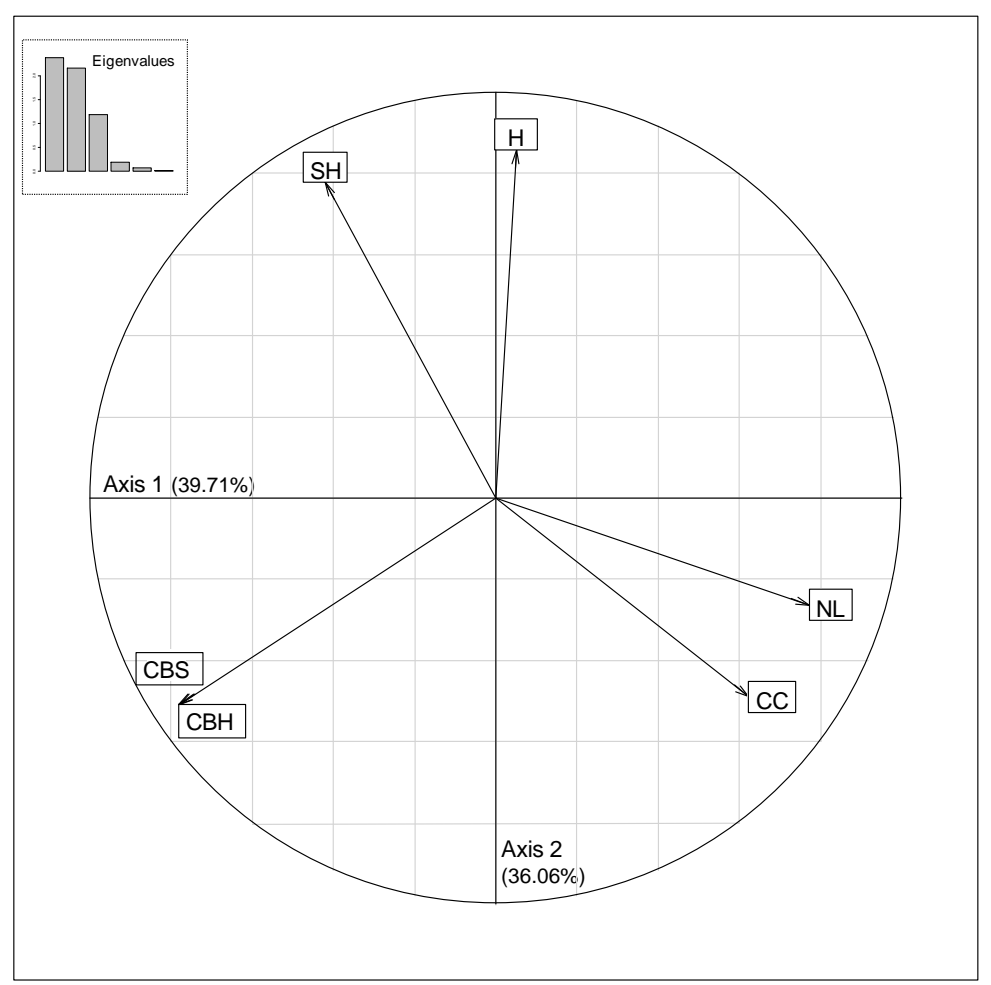

Fig. 5. The PCA using the structural variables of three palm tree species in Benfica. Circumference at breast height $(\mathrm{CBH})$, circumference at the base of the stipe (CBS), number of leaves (NL), total height $(\mathrm{H})$, stipe height $(\mathrm{SH})$, and crown circumference (CC).

In the PCA formed by the first and second axes, the structural variables were grouped according to palm tree type: babassu, inajá, and tucumã. According to a Monte Carlo test with 999 permutations, $44 \%$ of the data variance was explained by palm tree species, and this value was significant ( $p=0.001 ;$ Fig. 6). 


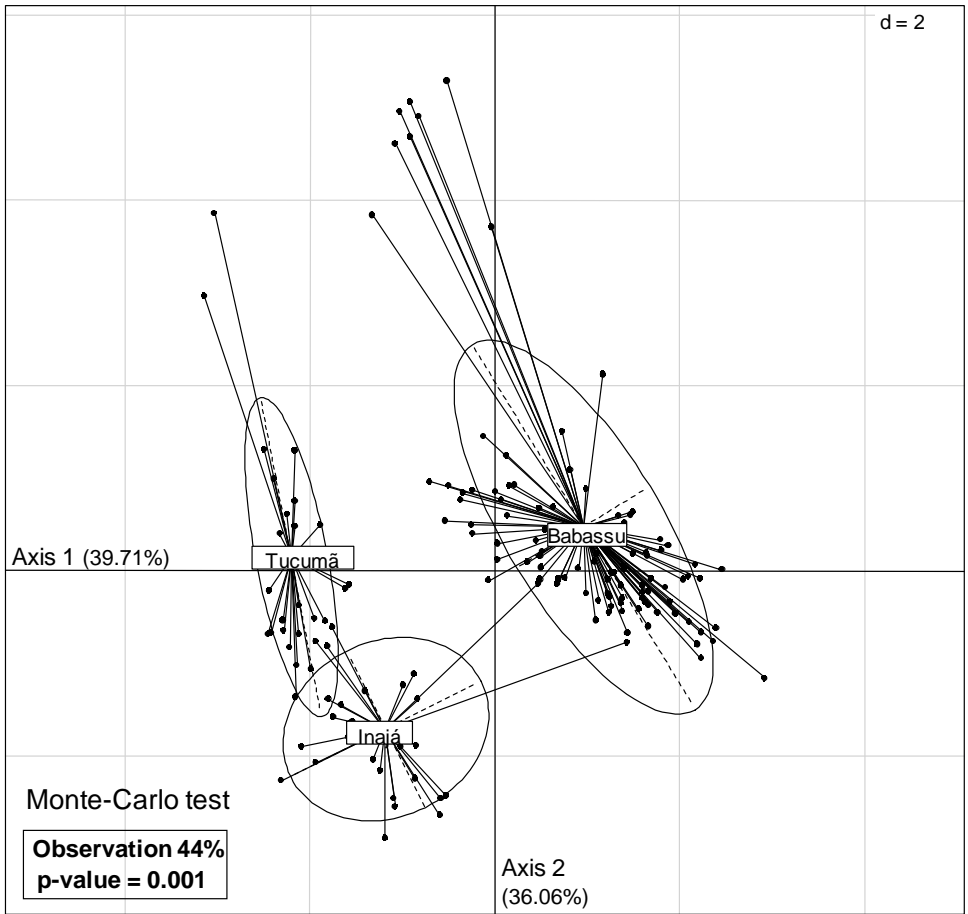

331 Fig. 6. The first and second axes of the PCA regarding the structural variables of the species

332 Attalea speciosa (Babassu), Attalea maripa (Inajá) and Astrocaryum aculeatum (Tucumã) in 333 Benfica.

3.2. The structural characteristics of the individuals detected/undetected by the algorithm The algorithm did not detect any of the stage 4 babassu palm trees identified in the 337 field.

When comparing the morphological characteristics of the stage 5 and 6 palm trees 339 using a boxplot (Fig. 7), we observed that the stage 6 palm trees had higher values and 340 significantly differed from those in stage 5 (Wilcoxon test, $\mathrm{p}<0.0001$ ) for all the structural characteristics analyzed. 

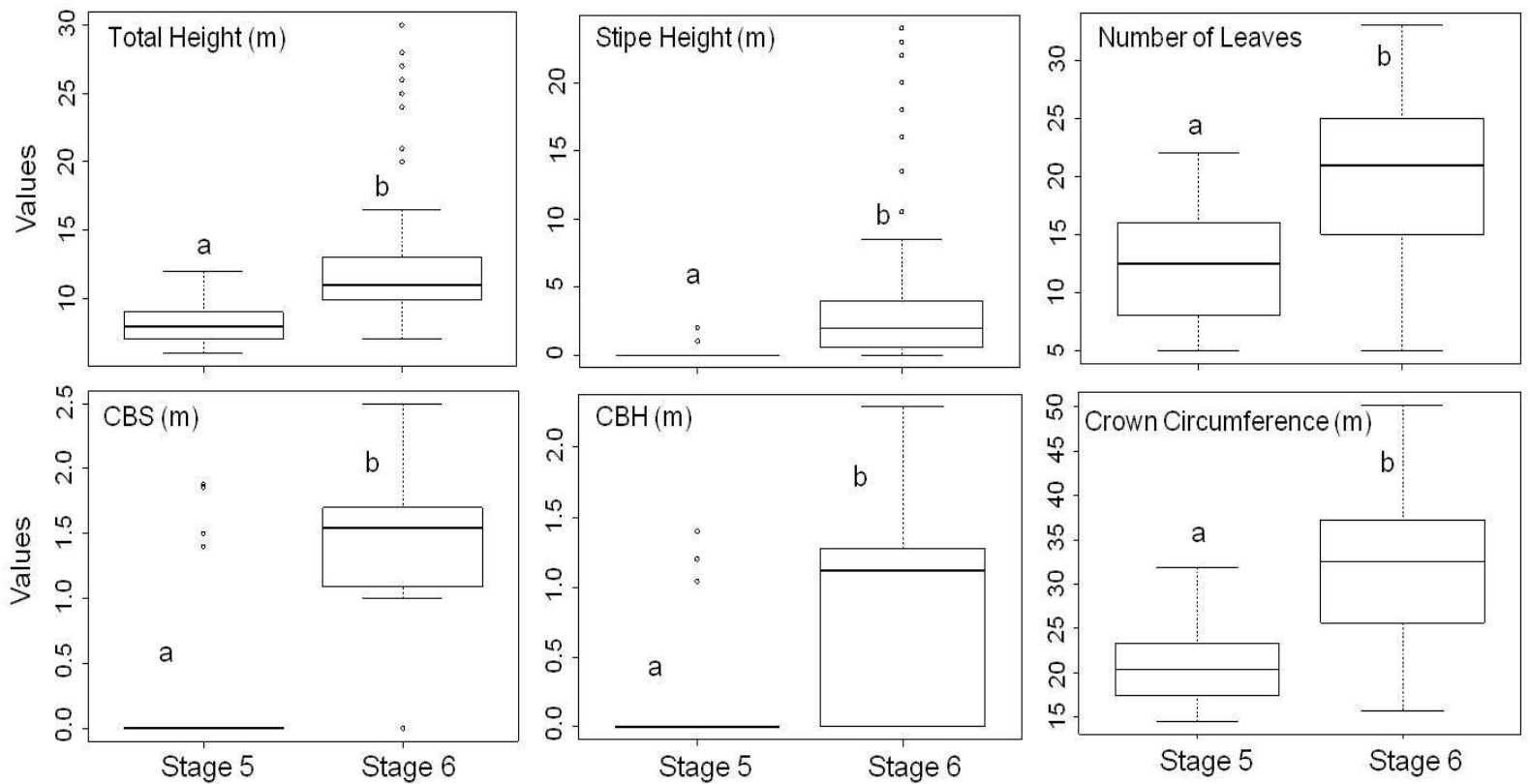

Fig. 7. A comparison of the morphological characteristics of stage $5(n=30)$ and stage 6 $(\mathrm{n}=105)$ Attalea speciosa palm trees. Each box of the plot extends from the data of quartiles 1

and 3; the horizontal lines within each box represent the median; and the circles at the extremities represent the values close to the box. The different letters indicate that the means are significantly different (Wilcoxon test, $\mathrm{p}<0.0001$ ). $\mathrm{CBH}$, circumference at breast height; CBS, circumference at the base of the Stipe.

Approximately $96 \%$ of the stage 6 palm trees identified in the field were detected using the algorithm based on their shadows; only $4 \%$ remained undetected. The comparison between the mean structural characteristics of the detected and undetected individuals revealed a significant difference (Wilcoxon test, $\mathrm{p}<0.05$ ) only for the mean stipe height, which was greater for detected palm trees than undetected palm trees (Table 1).

Approximately $60 \%$ of the stage 5 babassu palm trees identified in the field were detected using the algorithm, and $40 \%$ were not detected (Table 1). The total height and the number of leaves values of the detected and undetected individuals significantly differed 
359 (Wilcoxon test, $\mathrm{p}<0.05$ ), with detected individuals having larger morphological characteristic

360 values than their undetected counterparts.

362 Table 1. The morphological characteristics of stage 5 and 6 babassu palm trees, regardless of 363 detection using the algorithm in open areas. The means were compared using the non364 parametric Wilcoxon test. Ns: not significant; *: $\mathrm{p}<0.05$

\begin{tabular}{|c|c|c|c|c|c|c|c|}
\hline $\begin{array}{c}\text { Stage } 5 \\
(\mathrm{n}=30)\end{array}$ & $\begin{array}{c}\% \\
\text { Individuals }\end{array}$ & $\begin{array}{l}\text { Total } \\
\text { Height } \\
\text { (m) }\end{array}$ & $\begin{array}{l}\text { Stipe } \\
\text { Height } \\
\text { (m) }\end{array}$ & $\begin{array}{l}\text { Number } \\
\text { of Leaves }\end{array}$ & $\begin{array}{l}\text { Circumference } \\
\text { at the Base of } \\
\text { the Stipe }(\mathrm{m})\end{array}$ & $\begin{array}{c}\text { Circumference } \\
\text { at Breast } \\
\text { Height (m) }\end{array}$ & $\begin{array}{c}\text { Crown } \\
\text { Circumference } \\
\text { (m) }\end{array}$ \\
\hline Undetected & 40 & 7.33 & 0.00 & 9.33 & 0.00 & 0.00 & 20.37 \\
\hline Detected & 60 & $\begin{array}{c}8.25 \\
*\end{array}$ & $\begin{array}{c}0.38 \\
\text { Ns }\end{array}$ & $\begin{array}{c}14.61 \\
*\end{array}$ & $\begin{array}{l}1.66 \\
\text { Ns }\end{array}$ & $\begin{array}{l}1.21 \\
\mathrm{Ns}\end{array}$ & $\begin{array}{c}21.32 \\
\text { Ns }\end{array}$ \\
\hline $\begin{array}{l}\text { Stage 6 } \\
(\mathrm{n}=105)\end{array}$ & $\begin{array}{c}\% \\
\text { Individuals }\end{array}$ & $\begin{array}{l}\text { Total } \\
\text { Height } \\
\text { (m) }\end{array}$ & $\begin{array}{l}\text { Stipe } \\
\text { Height } \\
\text { (m) }\end{array}$ & $\begin{array}{l}\text { Number } \\
\text { of Leaves }\end{array}$ & $\begin{array}{l}\text { Circumference } \\
\text { at the Base of } \\
\text { the Stipe }(\mathrm{m})\end{array}$ & $\begin{array}{c}\text { Circumference } \\
\text { at Breast } \\
\text { Height }(\mathrm{m})\end{array}$ & $\begin{array}{c}\text { Crown } \\
\text { Circumference } \\
(\mathrm{m})\end{array}$ \\
\hline Undetected & 4 & 11.25 & 0.50 & 15.75 & 1.68 & 1.54 & 28.63 \\
\hline Detected & 96 & $\begin{array}{c}12.38 \\
\mathrm{Ns}\end{array}$ & $\begin{array}{c}3.94 \\
* \\
\end{array}$ & $\begin{array}{c}19.76 \\
\mathrm{Ns}\end{array}$ & $\begin{array}{l}1.60 \\
\mathrm{Ns}\end{array}$ & $\begin{array}{l}1.26 \\
\mathrm{Ns}\end{array}$ & $\begin{array}{c}31.87 \\
\mathrm{Ns}\end{array}$ \\
\hline
\end{tabular}

3.2. Algorithm quality and LCC palm tree density

When evaluating the performance of the algorithm used to automatically detect the

369 LCC palm trees, we considered 334 points, in which $252(75.45 \%)$ had been correctly

370 identified by the algorithm (true positives), 55 (16.47\%) points indicated by the algorithm that

371 did not correspond to palm trees (false positives), and $27(8.08 \%)$ points corresponding to

372 palm trees that were not identified by the algorithm (false negatives). This analysis resulted in

$37390.32 \%$ of Extraction, 0.218 of Branching factor, and $75.45 \%$ of Quality. 

the GeoEye1 2013 image. A total of 54,540 palm trees were detected in open vegetation in Benfica communities (6,870 ha). In the study area, $65 \%$ of the cells had a null density, less than $35 \%$ of the cells had a low LCC palm tree density (1 to 3 palm trees in a circle with a15 m-radius, corresponding to 14 to 42 palm trees per ha), and less than $2 \%$ of the cells had an average LCC palm tree density (4 to 9 palm trees in a circle with a 15 m-radius, corresponding to 56 to 127 palm trees per ha) (Fig. 9). The average-density areas were localized and dispersed, whereas the low-density and null-density areas occupied a large surface characterized by continuous areas.

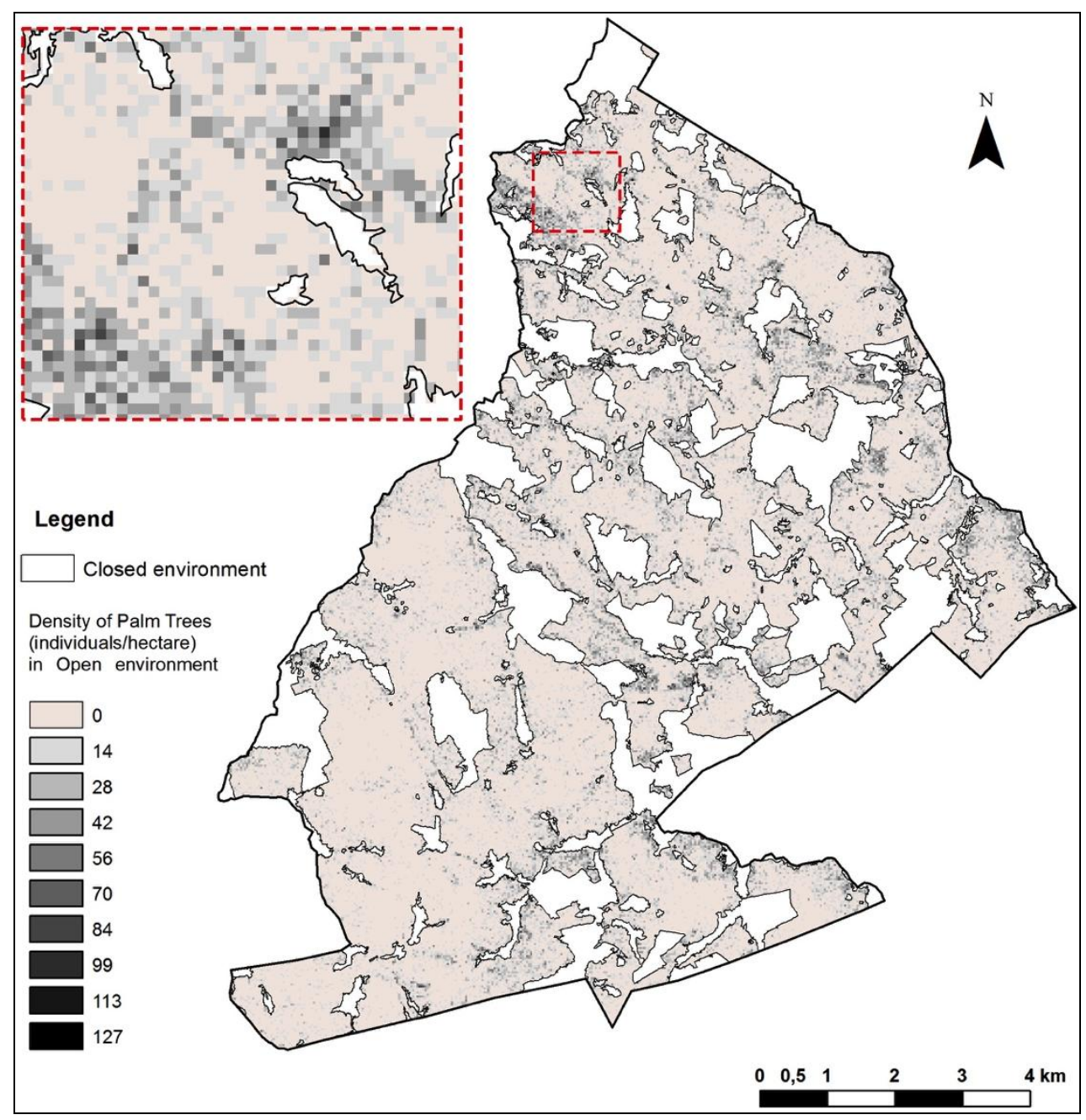

Fig. 8. The LCC palm tree density map in Benfica based on the application of automatic 


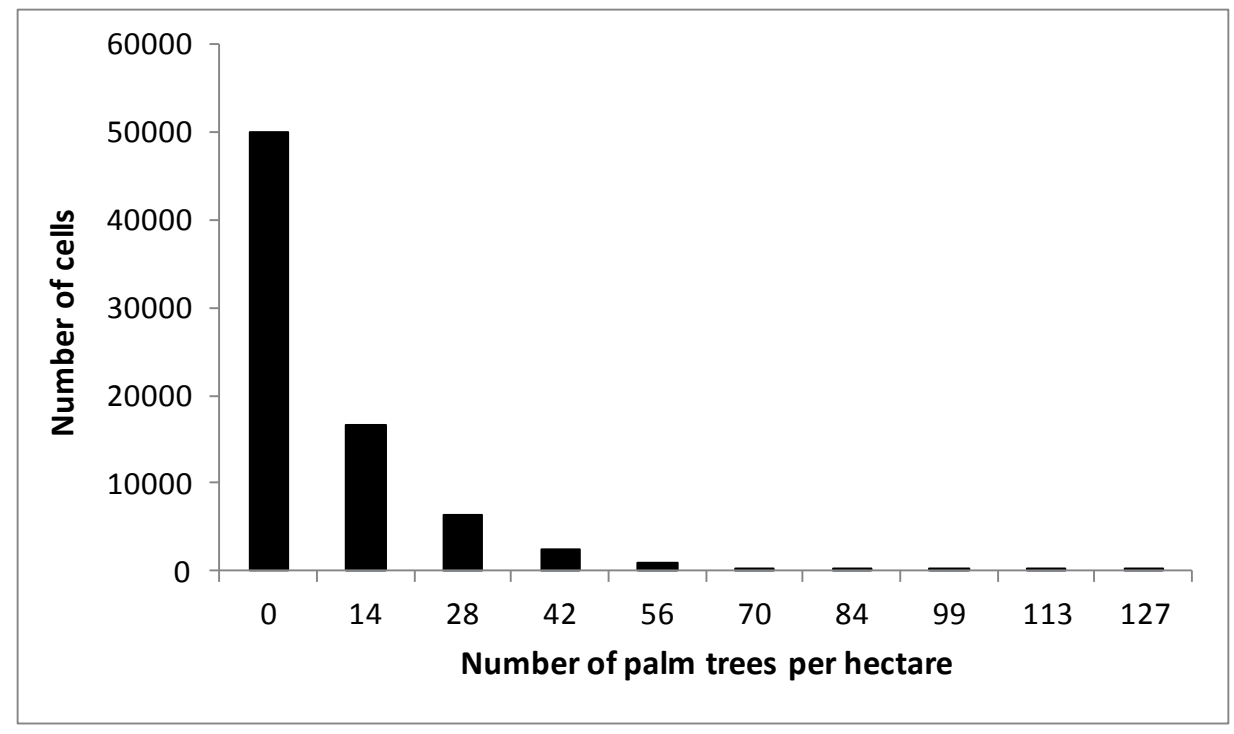

Fig. 9. A histogram of the number of cells as a function of palm tree density per ha in the density map obtained from the GeoEye1 2013 image

\subsection{Babassu resource density productivity estimate}

The 54,540 LCC palm tree points detected using the GeoEye1 2013 image of Benfica were corrected with regard to the algorithm's errors, resulting in 49,964 LCC palm trees actually present. By applying the $93.6 \%$ rate, we obtained 46,766 babassu palm tree based on the total number of LCC palm trees. Based on the field data of the proportion of stage 5 $(46.51 \%)$ and $6(53.49 \%)$ palm trees in the study areas, we calculated 25,015 of babassu individuals in stage 6 (adults). Finally, we estimated that the adults in the open areas of Benfica have an annual potential productivity of $27.4 \mathrm{t}$ of almond oil.

\section{Discussion}

4.1. The contribution of the field methods to validate the remote-sensing data The local densities obtained via automatic detection are accurate; however, this information becomes much more efficient when combined with the data obtained via field 
measurements (Zhou et al., 2013). In the present study, the measurements of the morphological characteristics of palm trees and their cartographic coordinates were essential to validate the remote-sensing data obtained using automatic detection.

As expected, it was not possible to differentiate between the LCC palm tree species in images with a resolution of $0.50 \mathrm{~m}$. However, these species have different structures. As Kahn (1986) reported, the genera Astrocaryum and Attalea have a variety of forms: the species Astrocaryum aculeatum has well-developed stipes (15 to $20 \mathrm{~cm}$ in diameter and 15 to $25 \mathrm{~m}$ in height), and its leaflets are always placed on different planes (Kahn, 1986). Conversely, Attalea speciosa has leaflets along the same plane (Kahn, 1986). Attalea speciosa can reach a height of 10 to $30 \mathrm{~m}$ and have a stipe diameter of 30 to $60 \mathrm{~cm}$ (May et al., 1985; Lorenzi et al., 2010), whereas Attalea maripa can reach a height of 7 to $24 \mathrm{~m}$, have a stipe diameter of 20 to $40 \mathrm{~cm}$, and leaves that are disposed in five directions (Lorenzi et al., 2010).

All of these forest palm trees grow in pastures and secondary vegetation (May et al., 1985; Anderson and Anderson, 1985; Kahn, 1986) where they usually reach sexual maturity earlier and grow to a smaller height than their counterparts in forests (Kahn, 1986). As palm trees increase in height, their crowns become relatively narrower (Rich et al., 1986).

The PCA of the structure of the LCC palm trees (Attalea speciosa, Attalea maripa and Astrocaryum aculeatum) present in the study area reinforces the differences in the architecture among the species and suggests that stipe circumference (axis 1) and height (axis 2) are the most important variables. Wang and Augspurger (2006) investigated the influence of palm tree crown architecture on seedling recruitment on Barro Colorado Island in Panama and La Selva forest in Costa Rica; based on a PCA, they concluded that the four palm tree species studied at each site had different growth forms and crown architectures, with the number of leaves and leaf area having the greatest influence on one axis and crown area influencing the other two axes. 
All of the structural variables analyzed in the present study influenced the shape of the shadow of each species because different architectures can have more or less impact on the way light propagates through vegetation (Wang and Augspurger, 2006). Because we used a shadow-detection algorithm that also considers the shape of the shadow, differentiating among LCC palm tree species might be possible if an image with a better spatial resolution (i.e., less than $0.50 \mathrm{~m}$ ) is used, given that these species have different structures. Moreover, it might be possible to create a density map specific for the babassu palm tree (Attalea speciosa) by extracting only the shadows that correspond to this species.

The validation of the information concerning stage 4,5 , and 6 of babassu palm tree, with the aid of field methods (i.e., structural census and georeferencing) regardless of the detection algorithm, enabled us to report which structural characteristics have a stronger influence on their detection using a high spatial resolution image.

Almost all (96\%) of the stage 6 babassu palm tree were detected using the high spatial resolution satellite images, and only $4 \%$ did not have visible shadows and were not automatically detected. The numbers of leaves and the crown widths of these individuals did not significantly differ from those detected; however, their stipes were significantly smaller.

In turn, the stage 5 babassu palm tree were partially detected (60\%). The $40 \%$ that were not detected were shorter and had fewer leaves than those detected. However, it is difficult to individually characterize the undetectable palm trees that belong to this stage based on their morphological characteristics, as was done for stage 6. Some individuals with similar morphological characteristics might not be detected because unmeasured factors might also influence shadow formation. These factors might include i) the orientation of the palm trees in relation to the sun when the image was captured by the sensor, ii) the leaf area (i.e., leaf width by blade length) of each individual (Wang and Augspurger, 2006), and iii) the average distance between leaflets (Wang and Augspurger, 2006). 

spatial resolution of the image used $(0.50 \mathrm{~m})$, given that the shadow of these individuals is nearly imperceptible or nonexistent under this resolution.

The babassu palm trees were divided into developmental stages to monitor the plant growth over time across different environments (i.e., forests, pastures, and secondary forests). Although this organization is biologically artificial, a continuum in babassu growth exists from the seedling to adult stages. The significant difference in the structure of individuals between stages 5 and 6 indicates that the separation of individuals into these life stages was well established. Although certain stage 5 individuals were similar to those in stage 6 , stage 6 palm tree usually have higher morphological characteristic values that explain their predominance among the detected plants. Because this species is native, non-cultivated, and non-domesticated where no selection is yet practiced, significant between-plant variability exists in the babassu population (Danielle Mitja, Personal communication).

\subsection{Algorithm performance for the automatic detection of LCC palm trees} The result of the detection via the algorithm (75.45\% quality) was promising given that it was applied to natural, non-planted areas. In commercial plantations of the African oil palm tree, organized along lines and without other species besides the cultivated one, the detection precision reaches $90 \%$ (Srestasathiern and Rakwatin, 2014); when high spatial resolution satellite images are used, this rate is approximately 95\% (Shafri et al., 2011). Even in homogeneous commercial plantations, however, issues might exist with the methods used because of the presence of objects other than the cultivated species, which are often detected as false positives (Srestasathiern and Rakwatin, 2014). Future studies should use texture information to suppress the presence of objects other than the species of interest (Srestasathiern and Rakwatin, 2014). 
In the present study, $75.45 \%$ of the LCC palm trees were successfully detected. However, this rate might be improved by decreasing the number of false positives (as reported above) and that of false negatives (for groups composed of 2 or 3 palm trees, only 1 palm tree is detected). In the case of a false negatives, the palm tree crowns might overlap, resulting in a single shape that differs from that of an isolated palm tree. Zhou et al. (2013) also faced the challenge of crown overlap; these authors were unable to detect the canopies of closely spaced trees on a Eucalyptus plantation. Moreover, Shari et al. (2011) noted that the crowndetection method applied worked well only for isolated African oil palm trees. All these studies used a spatial resolution of $0.50 \mathrm{~m}$ or greater. Better resolutions $(0.10-0.30 \mathrm{~m})$ for example using drones, and the improvement of the algorithm should decrease this error.

Using the LCC palm tree density map, we observed that this algorithm might be used to estimate the occurrence of palm trees present in the open area of interest using a high spatial resolution image $(0.50 \mathrm{~m})$. One of the major advantages of mapping species of interest via high-resolution images compared with forest censuses is that this information can be obtained for large areas (Zhou et al., 2013), as it is the case in the present study, especially because multispectral and hyperspectral images are becoming more accessible.

4.3. The potential use of this technique for babassu productivity monitoring, planning, and management

Automatic mapping in commercial plantations seeks to identify high-mortality points (Zhou et al., 2013) and the plants affected by disease (Shari et al., 2011; Johansen et al., 2014) to define management practices. In turn, the density map of the LCC palm trees over large areas proposed here, provides a wide view of resource distribution along the entire basin and enables the identification of areas with greater densities, access and productive potential, favoring the planning of resource exploitation and management based on the interests of land 
owners or producer associations. In addition, given the risk of overexploitation and species extinction, environmental agencies might use this tool to aid in the inspection of areas where babassu felling is prohibited by law (Porro et al., 2011) or to monitor the variation in resource density over time, as suggested by Aouragh et al. (2013) and Zhou et al. (2013) with regard to tree species.

Remote sensing, very high spatial resolution images, image processing, and object detection algorithms have become some of the major technologies in geospatial research, exploitation and monitoring of biodiversity (Bai et al., 2005; Clark et al., 2005; Schmidtlein et al., 2012; Engler et al., 2013; Garrity et al., 2013; Lin, 2013; Laurin et al., 2014), and commercial plantations of forest species of interest (Zhou et al., 2013; Srestasathiern and Rakwatin, 2014). The present paper seeks to contribute to the use of this technology by studying the native palm trees naturally and randomly dispersed and mixed with numerous other species.

Because babassu is a native species that is adapted to secondary environments (May et al., 1985; Anderson and Anderson, 1985), the expansion of the areas occupied by this species is directly related to the advancement of the agricultural frontier in the Amazon through deforestation (Teixeira, 2003). For many decades, this species has been the primary source of income for farmers in North and Northeast Brazil (Teixeira, 2003; Porro et al., 2011; Porro and Porro, 2014). However, the major hindrances within the production chain of babassu oil in Brazil are the lack of a regular supply system for quality raw materials and the scarcity of strategic partnerships with small farmers (Teixeira, 2003). The methods proposed in this study regarding the density and production capacity estimates based on the results of automatic detection will provide more precise results that might be used to simulate numerous exploitation scenarios based on different systems of fruit harvest, adult density management 
and species regeneration time. These systems might provide farmers with better plans of action for the constant and sustainable use of the production potential of this palm tree.

\section{Conclusions}

The result of the automatic detection using the algorithm on a very high spatial resolution image ( $75.45 \%$ quality) was promising, given that it was applied to natural, nonplanted areas.

The validation of the information concerning stage 4, 5, and 6 Attalea speciosa (babassu) palm trees using field methods (i.e., structural census and georeferencing), regardless of algorithm detection, provided information regarding which structural characteristics have a greater influence on their detection in a very high spatial resolution image. This step is important in the study of automatic detection using remote sensing images of palm trees.

By itself, the use of the algorithm on very high spatial resolution images does not yet deliver researchers a density map exclusively for babassu for farmers, associations or public policies. However, the detection of LCC palm trees and the implementation of auxiliary field methods to estimate the density of the species of interest is an important first step toward the large-scale monitoring of this important resource, not only by the Brazilian industry and economy but also by the thousands of families who depend on babassu extraction for subsistence.

\section{Acknowledgments}

The authors thank the Institut de Recherche pour le Développement, whose support enabled the development of this study. This project was also funded within the RELAIS (CNPq/IRD/UFRJ) and CNES TOSCA/Babaçu projects. Thanks go to the farmers for their 
553

554

555

556

557

558

559

560

561

562

563

564

565

566

567

568

569

570

571

572

573

574

575

576

577

receptivity and to Mr. Deurival da Costa Carvalho for his dedication to the fieldwork. This study was performed with support from the Brazilian National Council for Scientific and Technological Development (with a PhD scholarship sandwich in French) and the Brazilian Federal Agency for the Support and Evaluation of Graduate Education (with a $\mathrm{PhD}$ scholarship in Brazil).

\section{References}

Anderson, A.B., 1983. The biology of Orbignya martiana (Palmae), a tropical dry forest dominant in Brazil. Thesis (PhD), University of Florida. 196 p.

Anderson, A.B., Anderson, S., 1985. A ‘tree of life' grows in Brazil. Nat. Hist. 94 (12), 40-47.

Aouragh, M., Lacaze, B., Hotyat, M., Ragala, R., Aboudi, A.E., 2013. Cartographie et suivi de la densité des arbres de l'Arganeraie (Sud-ouest du Maroc) à partir d'images de télédétection a haute resolution spaciale. Revue Française de Photogrammétrie et de Télédétection 203, 3-9.

Araujo, F.R., Lopes, M.A., 2012. Diversity of use and local knowledge of palm trees (Arecaceae) in eastern Amazonia. Biodivers Conserv 21, 487-501. DOI: $10.1007 / \mathrm{s} 10531-011-0195-9$

Arnauld de Sartre, X., 2004. A Ruralisation of an Amazonian Frontier? In: SLAS Annual conference. Society for Latin American Studies, 19 p.

Bai, Y., Walsworth, N., Roddan, B., Hill, D.A., Broersma, K., Thompson, D., 2005. Quantifying tree cover in the forest-grassland ecotone of British Columbia using crown delineation and pattern detection. Forest Ecol Manag 212, 92-100. http://dx.doi.org/10.1016/j.foreco.2005.03.005

Barot, S., Mitja, D., Miranda, I., Meija, G.D., Grimaldi, M., 2005. Reproductive plasticity in an Amazonian palm. Evol Ecol Res 7, 1051-1065. 
578 Bertrand, G., 2009. Characterization of adaptive responses to water stress in the Southeast Amazon in three forage species grown in monoculture and in association: Brachiaria brizantha, Leucaena leucocephala et Arachis pintoi. Thesis (PhD), University of ParisEst. $181 \mathrm{p}$.

582

Clark, M.L., Roberts, D.A., Clark, D.B., 2005. Hyperspectral discrimination of tropical rain forest tree species at leaf to crown scales. Remote Sens Environ 96, 375-398.

Coelho, R.F.R., Miranda, I.S., Mitja, D., 2012. Description of sucessional process at Benfica Settlement Project, Southeastern of State of Pará, Eastern Amazon. Bol Mus Para Emílio Goeldi, Cienc Nat 7(3), 251-282.

Culvenor, D.S., 2002. TIDA: An Algorithm for the Delineation of Tree Crowns in High Spatial Resolution Remotely Sensed Imagery. Computer \& Geosciences 28, 33-44. http://dx.doi.org/10.1016/S0098-3004(00)00110-2

Da Rós, P.C.M., Silva, W.C., Grabauskas, D., Perez, V.H., Castro, H.F., 2014. Biodiesel from babassu oil: Characterization of the product obtained by enzymatic route accelerated by microwave irradiation. Ind Crop Prod 52, 313-320. http://dx.doi.org/10.1016/j.indcrop.2013.11.013

Demagistri, L., Mitja, D., Delaitre, E., Shahbazkia, H., Petit, M., 2014. Palm trees detection with very high resolution images, comparison between Geoeye and Pléiades sensors. http://www.pleiades2014.com/presentations-2014 (accessed 14.01.17).

Dias, F. B., Quartier, M., Diotaiuti, L., Mejía, G., Harry, M., Lima, A. C., Davidson, R., Mertens, F., Lucotte, M., Romaña, C.A., 2014. Ecology of Rhodnius robustus Larrousse, 1927 (Hemiptera, Reduviidae, Triatominae) in Attalea palm trees of the Tapajós River Region (Pará State, Brazilian Amazon). Parasit Vectors. 7, 154.

Dray, S., Dufour, A.B., 2007. The ade4 package: implementing the duality diagram for ecologists. Journal of Statistical Software 22(4), 1-20. 
Dray, S., Dufour, A.B., Chessel, D., 2007. The ade4 package-II: Two-table and K-table methods. R News 7(2), 47-52.

Engler, R., Waser, L.T., Zimmermann, E., Schaub, M., Berdos, S., Ginzler, C., Psomas, A., 2013. Combining ensemble modeling and remote sensing for mapping individual tree species at high spatial resolution. Forest Ecol Manag 310, 64-73.

Erikson, M., Olofsson, K., 2005. Comparison of three individual tree crown detection methods. Mach Vision Appl 16(4), 258-265.

Frazão, J.M.F., 2001. Alternativas econômicas para agricultura familiar assentadas em áreas de ecossistemas de babaçuais. Relatório Técnico, Governo do Estado do Maranhão, São Luis. 120pp.

Garrity, S.R., Allen, C.D., Brumby, S.P., Gangodagamage, C., McDowell, N.G., Cai, D.M., 2013. Quantifying tree mortality in a mixed species woodland using multitemporal high spatial resolution satellite imagery. Remote Sens Environ 129, 54-65. http://dx.doi.org/10.1016/j.rse.2012.10.029

Ghiyamat, A., Shafri, H.Z.M., 2010. A review on hyperspectral remote sensing for homogeneous and heterogeneous forest biodiversity assessment. Int J Remote Sens 31(7), $1837-1856$.

Giada, S., Groeve, T.D., Ehrlich, D., Soille, P., 2003. Information extraction from very high resolution satellite imagery over Lukole refugee camp, Tanzania. Int. J. Remote Sens 24 (22), 4251-4266.

Gonsalves, A.D., 1955. O Babaçu, considerações científicas, técnicas e econômicas. Ministério da Agricultura, Rio de Janeiro, Série Estudos e Ensaios n 8, 321p.

Haralick, R.M., Stenberg S.R., Zhuang X., 1987. Image analysis using mathematical morphology. IEEE $T$ Pattern Anal PAMI-9(4), 532-550. DOI: 10.1109/TPAMI.1987.4767941. 
Hirschmugl, M., Ofner, M., Raggam, J., Schardt, M., 2007. Single tree detection in very high resolution remote sensing data. Remote Sens Environ 110, 533-544.

IBGE, 2013. Produção da Extração vegetal e da silvicultura. IBGE, Rio de Janeiro, v. 28, 69p.

Jiang, M., Lin, Y., 2013. Individual deciduous tree recognition in leaf-off aerial ultrahigh spatial resolution remotely sensed imagery. IEEE Geosci Remote Sens Lett. 10, 38-42.

Johansen, K., Sohlbach, M., Sullivan, B., Stringer, S., Peasley, D., Phinn, S., 2014. Mapping Banana Plants from High Spatial Resolution Orthophotos to Facilitate Plant Health Assessment. Remote Sensing 6, 8261-8286. doi:10.3390/rs6098261.

Kahn, F., 1986. Adaptation en forêt tropicale humide: le cas des palmiers amazoniens. in: Hallé, F. (ed.), L'arbre: compte-rendu du colloque international. Naturalia Monspeliensia, Montpellier, p. 171-189.

Laurin, G.V., Chan, J.C.W., Chen, Q., Lindsell, J.A., Coomes, D.A., Guerriero, L., Frate, F. D., Miglietta, F., Valentini, R., 2014. Biodiversity Mapping in a Tropical West African Forest with Airborne Hyperspectral Data. PLoS ONE 9(6), e97910. http://dx.doi.org/10.1371/journal.pone.0097910

Lin, M.J.Y., 2013. Individual Deciduous Tree Recognition in Leaf-Off Aerial Ultrahigh Spatial Resolution Remotely Sensed Imagery. IEEE Geosci Remote Sens Lett 10(1), 3842.

Lorenzi, H., Noblick, L.R., Kahn, F., Ferreira, E., 2010. Flora brasileira - Arecaceae (Palmeiras). Plantarum, São Paulo, 384 p.

Luo, L., Wang, X., Guo, H., Liu, C., Liu, J., Li, L., Du, X., Qian, G., 2014. Automated Extraction of the Archaeological Tops of Qanat Shafts from VHR Imagery in Google Earth. Remote Sensing 6(12), 11956-11976.

Malek, S., Bazi, Y., Alajlan, N., Alhichri, H., Melgani, F., 2014. Efficient Framework for Palm Tree Detection in UAV Images. IEEE J-STARS 7(12), 4692-4703. 
Martins, R.C., Filgueiras, T.S., Albuquerque, U.P., 2014. Use and Diversity of Palm (Arecaceae) Resources in Central Western Brazil. The Scientific World Journal ID 942043, 14 pages. http://dx.doi.org/10.1155/2014/942043

May, P.H., Anderson, A.B., Balick, M.J., Frazão, J.M.F., 1985. Subsistence benefits from the babassu palm (Orbignya martiana). Econ Bot 39,113-129.

Mitja, D., Miranda, I.S., Velasquez, E., Lavelle, P., 2008. Plant species richness and floristic composition change along a rice-pasture sequence in subsistence farms of Brasilian Amazon, influence on the fallows biodiversity (Benfica, State of Pará). Agr Ecosyst Environ 124(2), 72-84.

Mitja, D., Ferraz, I., 2001. Establishment of babassu in pastures in Pará, Brazil. Palm trees 45(3), 138-147.

Mitja, D., Miranda, I.S. 2010. Weed community dynamics in two pastures grown after clearing Brazilian Amazonian rainforest. Weed Res 50, 163-173.

Montúfar, R., Anthelme, F., Pintaud, J.C., Balslev, H., 2011. Disturbance and Resilience in Tropical American Palm Populations and Communities. The Botanical Review 77(4), 426-461.

Pintaud, J.-C., Galeano, G., Balslev, H., Bernal, R., Borschenius, F., Ferreira, E., Granville, J. J., Mejía, K., Millán, B., Moraes, M., Noblick, L., Stauffer, F.W., Kahn, F., 2008. Las palmeras de América del Sur: diversidad, distribución e historia evolutiva. Revista Peruana de Biologia 15(Supl. 1), 7-29.

Porro, N., Veiga, I., Mota, D., 2011. Traditional communities in the Brazilian Amazon and the emergence of new political identities: the struggle of the quebradeiras de coco babaçu - babassu breaker women. Journal of Cultural Geography 28 (1), 123-146.

Porro, R., Porro, N.S.M., 2014. Social roots of resource use routes in rural Maranhão, Brazil. Journal of Rural Studies 36, 64-76. 
678 Pouliot, D.A., King, D.J., Bell, F.W., Pitt, D.G., 2002. Automated tree crown detection and

679

680

681

682

683

684

685

686

687

688

689

690

691

692

693

694

695

696

697

698

699

700

701

702 delineation in high-resolution digital camera imagery of coniferous forest regeneration. Remote Sens Environ 82, 322-334.

Protásio, T.P., Trugilho, P.F., César, A.A.S., Napoli, A., Melo, I.C.N.A., Silva, M.G., 2014. Babassu nut residues: potential for bioenergy use in the North and Northeast of Brazil. SpringerPlus 3 (1), 1. Doi:10.1186/2193-1801-3-124

R Core Team, 2014. R: a language and environment for statistical computing. R Foundation for Statistical Computing. http://www.R-project.org/ (accessed 14.01.17).

Rich, P.M., Helenurm, K., Kearns, D., Morse, S.R., Palmer, M.W., Short, L., 1986. Society Height and Stem Diameter Relationships for Dicotyledonous Trees and Arborescent Palm trees of Costa Rican Tropical Wet Forest. B Torrey Bot Club 113 (3), 241-246.

Ritter, L., Martins, P., Cooper, M., Grimaldi, C., 2009. Variação e possibilidades de uso do solo sobre rochas cristalinas na Amazônia oriental. Novos Cadernos NAEA 12(1), 225 246.

Sampaio, S.M.N., 2008. Dinâmica da paisagem e complexidade espacial de um Projeto de Assentamento da Amazônia Oriental. 2008. Thesis (PhD), Universidade Federal Rural da Amazônia. 175 p.

Santos, A.M., Mitja, D., 2011. Wooded cattle pasture in the benfica seetling project in Itupiranga, Pará, Brazil. Rev Arvore 35(4), 919-930.

Schmidtlein, S., Feilhauer, H., Bruelheide, H., 2012. Mapping plant strategy types using remote sensing. J Veg Sci 23, 395-405.

Serra, J., 1982. Image analysis and mathematical morphology. Academic Press, New-York.

Shafri, H.Z.M., Hamdan, N., Saripan, M.I., 2011. Semi-automatic detection and counting of oil palm trees from high spatial resolution airborne imagery. Int J Remote Sens 32(8), 2095-2115. http://dx.doi.org/10.1080/01431161003662928 
Shufelt, J.A., 1999. Performance evaluation and analysis of monocular building extraction from Aerial imagery. IEEE T Pattern Anal 21, 311-326. DOI: 10.1109/34.761262

Soille, P., Pesaresi, M., 2002. Advances in mathematical morphology applied to geoscience and remote sensing. IEEE T Geosci Remote 40, 2042-2055.

Srestasathiern, P., Rakwatin, P., 2014. Oil Palm Tree Detection with High Resolution MultiSpectral Satellite Imagery. Remote Sensing 6(10), 9749-9774.

Teixeira, M.A., 2003. Uma Agenda para o Babaçu. Revista Econômica do Nordeste 34(4), $562-575$.

Torres-Méndez, L.A., Ruiz-Suárez, J.C., Sucar, L.E., Gómez, G., 2000. Translation Rotation and Scale-Invariant Object Recognition. IEEE T Systems Man and Cybernetics, 30:125130. DOI: $10.1109 / 5326.827484$

Wang, Y.H., Augspurger, C., 2006. Comparison of seedling recruitment under arborescent palm trees in two Neotropical forests. Oecologia 147(3), 533-45.

Whiteside, T., Boggs, G., Maier, S., 2011. Extraction of tree crowns from high resolution imagery over Eucalypt dominant tropical savanna. Photogramm Eng Rem S 77 (8), 813824.

Zhang, J., Rivard, B., Sánchez-Azofeifa, A., Castro-Esau, K., 2006. Intra- and inter-class spectral variability of tropical tree species at La Selva, Costa Rica: Implications for species identification using HYDICE imagery. Remote Sens Environ 30 105(2), 129-141. http://dx.doi.org/10.1016/j.rse.2006.06.010

Zhou, J., Proisy, C., Descombes, X., Le Maire, G., Nouvellon, Y., José-Luiz, S., Viennois, G., Zerubia, J., Couteron, P., 2013. Mapping local density of young Eucalyptus plantations by individual tree detection in high spatial resolution satellite images. Forest Ecol Manag 301, 129-141. http://dx.doi.org/10.1016/j.foreco.2012.10.007 